\title{
Patterns of Weaning and Its Impact on Infants' Weight in a Rural Lower Egypt
}

\author{
Ahmed E Shouman *, Nahla FAbul-Ezz *, Sahar k Kandil *, Amira M \\ Mohamed $^{* *}$ \\ * Department of Community, Environmental and Occupational Medicine, Faculty of \\ Medicine, Ain Shams University \\ *** Family Physician, MOHP
}

\begin{abstract}
Background Optimal nutrition is of crucial importance for normal growth especially in the first two years of life. Appropriate complementary feeding is important to achieve normal growth.

Objective: To describe the process of complementary feeding (weaning) and to identify its effect on infants' weight, six to 24 months of age in a rural area in Lower Egypt.

Methodology: A cross-sectional study, including 200 mothers/infant pairs (six to 24 months) coming for immunization or follow up, was conducted in one of the primary health care unites, in Qaluobia Governorate. Demographic data, the process of complementary feeding, and occurrence of diarrhea or cough within the previous two weeks, were inquired about. Infants' weight and length were measured. Descriptive and analytical bivariate and logistic regression was performed. Significance was at P-value $\leq$ 0.05 .
\end{abstract}

Results: The percentage of normal infants' weight was 56\%. The percentages of stunting, under- and over-weight were $26 \%, 25 \%$, and $19 \%$ respectively; indicating the double burden malnutrition problem. The majority of mothers $(82.3 \%)$ began complementary feeding before six months with reported high percentage of diarrhea $(38.5 \%)$. Minimum acceptable diet was received by $27.6 \%$ of infants, mainly, because of a poor diversity of food groups. The most frequently fed food groups were dairy products $(95 \%)$, grains, roots and tubers $(86.5 \%)$ and the least were the fruit and vegetables $(33 \%)$ and vitamin $\mathrm{A}$ rich group (25.5\%) Normal infants' weight was four fold higher among normal birthweight infants than low birth-weight (OR: 3.89, 95\% CI: $1.07-14.22$ ). It was not significantly affected by the age of introduction of any of food groups.

Conclusion: Infants' malnutrition is still a common problem in our community. Three quarter of infants does not receive the minimum acceptable diet mainly, because of poor diversity. Interventions to improve feeding practice are required to address the dual burden of stunting/over-weight.

Key words: Complementary Feeding, Stunting, Infants' weight, Malnutrition

Corresponding author: Sahar Khalil Kandil e-mail: sahar_kandil@yahoo.com

\section{Introduction}

Optimal nutrition is of crucial Infants in their first two years of life are importance for the normal growth. in a critically important period of rapid 
growth during which they should receive their adequate nutritional requirements. This period is regarded as "the window of opportunity to prevent malnutrition" $(1,2)$.During this period, poor nutrition will permanently have a negative effect on the health of the individual in the form of impaired cognitive development and higher probability of illness and death ${ }^{(3,4)}$. This effect will extend to the future life and will manifest, during childhood, as lower scholastic achievement as well as low productivity in the adult life. Therefore, malnutrition has both a direct cost on the health care system and indirect one in the form of loss of human productivity. The consensus opinion of expert in the WHO and UNICEF recommend exclusive breast feeding for the first six months of life and starting of appropriate complementary feeding from six month with continuation of breastfeeding until two years or beyond. They also prohibiting introduction of food before four months of age ${ }^{(5)}$. Egypt is ranked among the 34 countries with highest malnutrition burden in which $90 \%$ of the world's stunted children are Egyptian ${ }^{(6)}$. It faces the dual burden of malnutrition with a persistently high rate of stunting/underweight as well as overweight among young children since 1990s ${ }^{(7)}$. The practice of weaning as a process of introduction of complementary feeding among Egyptian women is subject to many challenges regarding aspects such as timing of beginning, the frequency and diversity of introduced foods as well as the nutritious value of the foods selected. Early beginning of complementary feeding before four months of age was not uncommon, and at the age of four and five months was the usual norm. The rate of exclusive breastfeeding was $79 \%$ before two months of age, to be dropped to $30 \%$ at $4-5$ months. Appropriate complementary feeding was met-with only among $40 \%$ of infants ${ }^{(8)}$. Some studies are relating the early beginning of complementary feeding before four month to the rapid weight gain in infancy, which may have an implication on obesity during childhood ${ }^{(9)}$.

Hence, the practice of complementary feeding (weaning) needs to be evaluated with its effect on infants' growth.

Objective: This study was aiming at describing the process of complementary feeding (weaning) and identifying its effect on infants' weight, six to 24 months of age in a rural area in Lower Egypt.

\section{Methodology}

\section{Study design, sample, and tools}

A cross-sectional study was carried out on 200 women having infants from six to 24 months of age and coming for immunization or for follow up in the well baby clinic in a primary healthcare unit in Qaluobia Governorate, Toukh district. The selected health care unit serves 2 villages and 11 manors and the number of inhabitants in the catchment area is 16820.The sample size was estimated to be 178 based on the assumption that the prevalence of inappropriate complementary feeding was $60 \%{ }^{(8)}$ with the worse accepted result set to be $\pm 7 \%$. Data were collected on a weekly basis during a five-month period, from the beginning of September 2013 to the end of January 2014. All women attended the 
health care unit and agreed to participate were included. Women, whose infants were suffering from conditions that may affect their normal growth such as psychomotor retardation, hormonal disorders, debilitating diseases (liver or kidney diseases), congenital heart diseases, and other similar conditions, were excluded. An interview questionnaire was designed and used for data collection after being field tested, for the appropriateness and comprehension of its questions, on a sample of 20 women selected from the same study healthcare unit and performing the necessary rephrasing. It included demographic data for both mother and infant, as well as infant's order and weight at birth. The process of complementry feeding was inquired about and included the type of food at the beginning of weaning, age of introduction of the cluturally common food items from each food group, condition of breastfeeding and age of complete cessation of breastfeeding. Inquiring about the number and severity of attacks of diarrhea and symptoms of acute respiratory tract infection (ARI) within the previous two weeks, if any, was done. A reference period of two weeks was selected to minimize the reporting error. Infant weight was measured, undressed with a clean disposable diaper, using Seca infant scale and recorded to the nearest $0.1 \mathrm{~kg}$. The recumbent infant length was measurement to the nearest $0.1 \mathrm{~cm}$, using plastic length boards

\section{Definition of variables:}

Social status was considered high in families with monthly expenditure more than 2000 pounds, having full-automatic washing machine, and the number of family members was $\leq 5$.

Diarrheal or URTI attacks were considered sever with those requiring hospital referral and/or admission.

Infants' weights were classified for their ages according to WHO charts. Under weight was considered when weight for age $\mathrm{Z}$-score $(\mathrm{WAZ})<-2 \mathrm{SD}$, and overweight when (WAZ) $>+2 \mathrm{SD}^{(10)}$.

Stunting was considered when the length for age z-score $(L A Z)<-2$ SD

Assessment of the complementary feeding practice was according to the WHO "indicators for assessing infant and young child feeding practices" (11). Following are the indicators definitions: A - Dietary diversity: infants were considered receiving the minimum dietary diversity if four or more of the seven food groups were received for infant more than six months and two or more groups for infants less than six months of age. This lowering of the cutoff point was performed for the limited probability to find infants consuming more than two food groups at this young age. The seven foods groups are 1 -Grains, roots and tubers 2 Legumes and nuts 3 - Dairy products (milk, yogurt, cheese) 4 - Flesh foods (meat, fish, poultry and liver/organ meats) 5 - Eggs 6 - Vitamin-A rich fruits and vegetables 7 - Other fruits and vegetables $B$ - Meal frequency: minimum meal frequency was considered to be fulfilled when infants received solid, semi-solid, or soft foods 2 times for breastfed infants $6-8$ months, 3 times for breastfed children 9-23 months, and 4 times for non-breastfed children 6-23 months. "Meals" include 
both meals and snacks (other than trivial amounts). C - Minimum acceptable diet: was considered when infants received both the minimum dietary diversity and minimum meal frequency.

\section{Data Management and Analysis:}

The collected data were coded and revised for completeness and precision. Data entry, management, and analysis were performed using Statistical Package for Social Science (SPSS) version $17^{(12)}$.

Both descriptive and analytical statistics were performed: mean, standard deviation (SD), minimum and maximum, for numerical data, and percentage for categorical data were calculated.

Chi-Square test was calculated to test for differences between proportions. $\mathrm{P} \leq$ 0.05 was considered significant. Binary logistic regression of normal infants' weight was used for variables that showed a p-value of $<0.1$ by chi square test.

\section{Results}

Two hundred mother/infant pairs were included in this study. The mean age of mothers, their mean age of marriage, and their mean age at giving birth to that infant were $26 \pm 4.9,20.4 \pm 2.5 \quad 24.8 \pm$ 4.9 years respectively. The mean family size was $4.6 \pm 1.4$ individuals. The majority of mothers were either secondary school, or university graduates ( $47 \%$ and $36.5 \%$ respectively), however, the proportion of working for cash mothers was $22.5 \%$. High social status was observed among $32.5 \%$ of mothers. Most of infants (88.5\%) were having the order of third or less among their siblings and girls constituted $49 \%$ (table 1).

The majority of infants $(88.5 \%)$ was born with normal weight, and above normal birth-weight was not reported with any of them. Normal weight was measured among $56 \%$ of infants. The percentages of under- and over-weight were $25 \%$ and $19 \%$ respectively and stunting percentage was $26 \%$. History of mild and sever diarrhea was reported by $33 \%$ and $5.5 \%$ of mothers respectively and cough was reported by $47.5 \%$ of mothers within the past two weeks of the interview. Cough was accompanied by short, rapid, or difficult breathing in $8.0 \%$ of cases (table 1 ). Treatment was given in $91.6 \%$ of cough conditions; in the form of antibiotics $(68.4 \%)$, or cough medicine and/or antipyretic (81.1\%).

Table (2) shows that the median age of introduction of complementary feeding (weaning) was five months (range 2 - 10). Out of 192 mothers who began to complementary feed their infants, $158(82.3 \%)$ did it before six months of infant's age (before four months among $19.3 \%$ and from 4 to $<6$ months among 63\%). The most commonly used food groups, in their order of frequency, were dairy products (95\%), grains, roots and tubers $(86.5 \%)$, eggs $(74.5 \%)$, flesh foods $(70 \%)$, legumes and nuts (58\%), other fruit and vegetables $(33 \%)$, and vitamin $\mathrm{A}$ rich foods $(25.5 \%)$. The use of fortified baby food was very limited (13.5\%). Dairy products, mostly in the form of yogurt, were introduced before six months among 78.9\% (150/190) infants (before 
4 months among (20/190) $10.5 \%$ and from 4 to $<6$ months among (130/190) $68.4 \%$ ) with a median age of five months (range 2 - 11). The median age of introduction of Grains, roots and tubers was five months (range 3 - 14) and $61.3 \%(106 / 173)$ of mothers introduced them before 6 months of infants' age, most commonly in the form of rice, mashed potatoes and boiled wheat (bellela). Flesh foods were introduced at 6 to $<9$ months among $63.6 \%$ (89/140) of infants. Their median age of introduction was 8 months (range 5 - 16) mostly in the form of chicken liver or its meat or, less commonly, meat. The median age of introduction of Eggs was seven months (range 5 - 14) and $78.5 \%(117 / 149)$ of mothers introduced it from 6 to $<9$ months. Legumes and nuts were introduced, mostly in the form of bean and lentil, at a median age of 6 months (rang 4 -12) with $48.3 \%(56 / 116)$ of mothers introduced them at 4 to $<6$ moths. Vitamin A rich foods were introduced at a median age of 6 months (rang 5 - 12), with $78.4 \%(40 / 51)$ of infants received it at 6 months or later, mostly in the form of carrot, and, less commonly, apricot or mango. Other fruits and vegetables were introduced at 6 months or more among $68.2 \%$ (45/66) of infants with a median age of 6 months (range 5 - 13). The intake of ordinary adult-form milk (powder, or cow's or other animals) began at a median age of 12 months (range 9 - 24) and 49.2\% (59/120) of infants received it at the 12 to < 18 months of age. Complete cessation of breastfeeding occurred at a median age of 18 months (range 12 - 24). Assessment of complementary feeding practice revealed that minimum dietary diversity, minimum meal frequency, and minimum acceptable diet were achieved among $\quad 31.8 \% \quad(61 / 192), \quad 61.5 \%$ $(118 / 192)$, and $27.6(53 / 192)$ of infants respectively.

Factors that may affect normal infants' weigh were analyzed in table (3). On bivariate analysis, the proportion of normal weight infants was significantly higher among younger age (25 years or less) than older age mothers (63.2\% versus $46.2 \%$ ), and housewives than working for cash mothers $(60.0 \%$ versus $42.2 \%$ ). Infants born with normal weight were having significantly higher proportion of normal current weight than those born with below normal weight (59.9\% versus $26.1 \%$ ). The proportion of infants with normal weight was significantly higher among those who began complementary feeding before 6 months of age than later beginning (65.2\% versus 26.5$)$, those who received dairy products at the 4 to $<6$ months of age compared to both earlier or later receivers $(73.8 \%$ versus $25.0 \%$ and $27.5 \%$ respectively), those who received grains, roots and tubers at the 6 to $<9$ months of age compared to earlier or later receivers $(69.1 \%$ versus $64.2 \%$ and $8.3 \%$ respectively), and those who received protein food at the 6 to $<9$ month of age compared to earlier or later receipt $(66.1 \%$ versus $42.9 \%$ and $44.1 \%$ respectively). Significantly higher proportion of infants with normal weight was observed with those with negative history of diarrhea within the past two weeks compared to those with mild or sever attacks $(64.2 \%$ versus $47.0 \%$ and $18.2 \%$ respectively). Infants' weight was not significantly associated with the mothers' level of education, social status 
of the family, his/her gender, his/her birth order, age of introduction of either of milk or legumes and nuts.

Multivariate analysis was performed to find out the variables that independently affected normal infants' weight. Out of the studied variables, only infants' weight at birth was retained in the regression model (table 3). The probability of having infants with normal weight was about four times among those who were born with normal weight that among those who were having low birth weight (OR: 3.89, 95\% CI: 1.07 14.22). Neither the demographic, nor the age of introduction of any of the food groups significantly affected infants' weight.

\section{Discussion:}

The current study results showed that about half of the studied infants were at a normal weight for age $(56.0 \%)$. The proportions of under- and over-weight were $25 \%$ and $19 \%$ respectively and the proportion of stunting was $26 \%$. The percentages of under- and overweight are much higher than the national figures reported in 2014 Demographic and Health Survey (DHS) that were $7.5 \%$ and $4.6 \%$ for under- and over-weight respectively among infants six to 24 months of age ${ }^{(13)}$. Our finding may be explained by the documented extremely higher percentage of diarrhea among our study participants than that reported in the 2014 DHS (38.5\% versus $14.4 \%$ ) with its acute effect on infants' weight (13). Regarding the percentage of stunting, it was $26 \%$ among our study participants and its national rate reported in 2014 DHS was about 20\% (13). However, two recently published studies that were conducted in Egyptian villages revealed relatively comparable results to those derived from our data. The first was a cohort study conducted on infants from birth to one year of age in Egyptian villages both in Upper and in Lower Egypt. They found one-quarter of infants were stunted and about a third were overweight by the end of their first year of life in Lower Egypt villages ${ }^{(14)}$. The second was a cross-sectional study in Lower Egypt and reported that the rates of under- and over-weight were $17.9 \%$ and $1.3 \%$ respectively ${ }^{(15)}$. This later study also reported a high rate of occurrence of diarrhea (55\%) and documented its association with stunting ${ }^{(15)}$. Our finding enhanced the notion of double burden problem of malnutrition with high rate of both stunting and overweight that both needing to be addressed especially in our rural communities.

Cough was very commonly reported (47.5\%) among our study participants; however, acute respiratory infection (ARI) was only reported to occur by $8 \%$ of mothers - as indicated by short, rapid, or difficult breathing. The nationally reported rate of cough in 2014 DHS was $27.3 \%$ and the rate of ARI was $18.1 \%$ (13). Limiting comparability with our results, the fact that respiratory infection is usually subject to seasonal variation, therefore, our data represents the situation in autumn/winter (data were collected between the beginning of September to the end of January). Moreover, data concerning the ARI symptoms are prone to reporting error even though short reference period (two 
weeks) was asked about to reduce this likelihood.

The proportion of mothers who perceived their infants as having less than average birth-weight was $11.5 \%$, less than the national reported rate $(17 \%)$ in the 2014 DHS ${ }^{(13)}$. Such data type is subjective in nature; hence, great variability is possibly high.

The majority of mothers $(82.3 \%)$ began complementary feeding before the six months of infants' age, earlier than recommended by the $\mathrm{WHO}$, hence, lowering the rate of exclusive breastfeeding. This finding was not surprising as the 2014 DHS reported that the rate of exclusive breastfeeding dropped to $12.5 \%$ by the age of $4-5$ months ${ }^{(13)}$, which was the age at which most of our study participants had began complementary feeding. Feeding usually began with dairy products, mainly yogurt, then rice and mashed potatoes. As shown from the frequency of feeding infants by different food groups, great deficiency in the fruits and vegetables group and vitamin A rich foods group (33\% and $25.5 \%$ respectively) was observed. The eggs and flesh foods groups, though mentioned to be used for feeding among three quarters of participants $\quad(74.5 \%$ and $70 \%$ respectively), they were not given daily, as recommended by the WHO (16). Vitamin rich food, fruits and vegetables, eggs, and flesh foods were not taken daily. Fortified baby foods were also of limited use. These finding suggests the vulnerability of such infants to nutritional deficiency of important vitamins and minerals. The composite indicator of feeding assessment, "the minimum acceptable diet", was achieved by only a quarter of infants $(27.6 \%)$ which indicates a poor feeding practice among three quarters of our mother/infants pairs. This indicator, being composite, was affected by both the frequency and diversity indicators. The required food diversity and meal frequency were achieved among 31.8\% and $61.5 \%$ of participants respectively. Hence, the poor feeding practice was mainly due to less diversity of the groups used for feeding infants. These findings were enhanced by the similar national results reported in 2014 DHS where the minimum acceptable diet, the minimum dietary diversity, and minimum meal frequency were $28.2 \%, 34.4 \%$, and $57.6 \%$ respectively ${ }^{(13)}$. It was also confirmed by results of the cohort study conducted in Egyptian villages, which found nearly the same results ${ }^{(14)}$. Much effort was done to deal with this problem from the aspect of raising awareness and counseling, however, economic factors may play an important role in such condition. Food prices, especially fruits, vegetables, and animal sources of protein, have been showing a continuous rise since $200{ }^{(17)}$. Reinforcing this notion was the reported association of micronutrient consumption with the maternal wealth and the area of residence $^{(18)}$.

Normal infants' weight was found to be about four-fold higher among infants with normal weight at birth (OR: 3.89, $95 \%$ CI: 1.07 - 14.22). In line with our finding, is the previously reported results suggesting the relationship between low birth weight and likelihood of stunting with a biologically plausible explanation 
of a continuum of inadequate nutrition for both mother and infant ${ }^{(19,20)}$. This finding mandates addressing the health and nutrition of not only infants but also mothers, and in a broader since, females since childhood onwards.

The data herein could not demonstrate any relationship of infants' weight with any of the demographic or social factors, or the age of introduction of different food items. Early beginning of complementary feeding is very common among Egyptian mothers. The consensus expert opinion and WHO recommendation is to begin complementary feeding at six months of age because it is the safest especially in conditions of poor sanitation in developing countries and that the earlier introduction of complementary feeding will not improve growth even in conditions with well nutritious and microbiologically safe food. They also concluded that, on a population level, exclusive breastfeeding for six months would not adversely affect infants' growth (21) On the other hand, the European Food Safety Authority Panel on Dietetic Products, Nutrition and Allergies delivered a scientific opinion on the appropriate age for introduction of complementary infants' food. The panel concluded that introduction of food at the age of 4 to 6 months, but not earlier than 4 months, is safe for some of the healthy term infants. They also added that it does not seem to have any effect on the rate of growth, the risk of subsequent development of obesity, type 2 diabetes, or cardiovascular disease ${ }^{(22)}$. The results of the current study demonstrating that infants' weight has no relation with the age of introduction of food and that Egyptian mother are more often than not to begin early complementary feeding. It also showed a very high rate of occurrence of diarrheal attacks $(38.5 \%)$ which might be a consequence of unsafe food preparation. Among the cultural factor that encourage early introduction of food is the belief of insufficient breast milk either in quantity or in quality with a strong reinforcement from influential family members such as grandmother and mother-in-low ${ }^{(23)}$ Such factors are still required to be addressed during interventions that aiming to improve infants feeding specially when dealing with rural communities, and taking into accounts the dual burden of stunting and over-weight.

\section{Conclusion:}

Infants' malnutrition is still a very common problem in our community. Low rate of normal infants' weight was observed (56\%) among six to 24 months infants living in a rural Lower Egypt. The rates of stunting, under- and overweight were $26 \%, 25 \%$, and $19 \%$ respectively indicating the double burden malnutrition problem. The majority of mothers (82.3\%) began complementary feeding before six months of infants' age with reported high rate of diarrhea (38.5\%). Minimum acceptable diet was only received by $27.6 \%$ of infants, mainly, because of a poor diversity of food groups. Normal infants' weight was significantly associated with normal birth weight. Interventions aiming to improve infant feeding practice are required to address the dual burden of stunting and overweight. 


\section{References}

1) Shrimpton R, Victoria CG, de Onis M, Lima RC, Blossner M, Clugston G. Worldwide timing of growth faltering: implications of nutritional interventions. Pediatrics. 2001 May;107(5):e75

2 ) Victoria CG, de Onis M, Hallal PC, Blossner M, Shrimpton R. Worldwide timing of growth faltering: revisiting implications of nutritional interventions. Pediatrics.2010;125(3):e473-e480

\section{3 ) Martorell R, Khan LK, Schroeder} DG. Reversibility of stunting: epidemiological findings in children from developing countries. European Journal of Clinical Nutrition. 1994; 48 Suppl1:S45-S57.

4 ) Walker SP, Wachs TD, Gardener JM, et al. Child development: risk factors for adverse outcome in developing countries. Lancet. 2007; 369(9556):145-157

5 ) WHO/UNICEF. Global strategy for infant and young child feeding. WHO/UNICEF, 2003.

6 ) Black R.E., Victora C.G.,Walker S.P., Bhutta Z.A., Christian P., de Onis M. et al. Maternal and child undernutrition and overweight in lowincome and middle-income countries. Lancet. 2013 382: 427-451.

7 ) UNICEF. Tracking Progress on Child and Maternal Nutrition: A survival and development priority. UNICEF 2009.

8 ) El-Zanaty, Fatma and Ann Way. Egypt Demographic and Health Survey
2008. Cairo, Egypt: Ministry of Health, El-Zanaty and Associates, and Macro International 2009.

9 ) Sloan S, Gildea A, Stewart M, Sneddon H, Iwaniec D. Early weaning is related to weight and rate of weight gain in infancy. Child: care, health and development. 2007;34(1) 59-64

10 ) WHO Multicentre Growth Reference Study Group. WHO Child Growth Standards: Length/height-forage, weight-for-age, weight-for-length, weight-for-height and body mass indexfor-age: Methods and development. Geneva: World Health Organization, 2006

11 ) WHO. Indicators for Assessing Infant and Young Child Feeding Practices. Parts 1,2,3 Series. World Health Organization. 2008 Geneva, Switzerland

12 ) SPSS Inc. Released 2008. SPSS Statistics for Windows, Version 17.0. Chicago: SPSS Inc.

13 ) Ministry of Health and Population [Egypt], El-Zanaty and Associates [Egypt], and ICF International.2015. Egypt Demographic and Health Survey 2014. Cairo, Egypt and Rockville, Maryland, USA: Ministry of Health and Population and ICF International.

14 ) Kavle, J. A., Flax, V. L., Abdelmegeid, A., Salah, F., Hafez, S., Ramzy, M., Hamed, D., Saleh, G., andGalloway, R. Factors associated with early growth in Egyptian infants: implications for addressing the dual burden of malnutrition. Matern Child Nutr. 2016;12: 139-151. 
15 - Barakat AA, Nada KH, Ezzat DA. Prevalence and determining factors of anemia and malnutrition among egyptian children. Indian J Med Sci 2013;67:16877

16 - Dewey KG. Guiding Principles for Complementary Feeding of the Breastfed Child. PAHO/WHO, 2003.

17 - International Food Policy Research Institute (IFPRI) \& World Food Programme (2013) Tackling Egypt's rising food insecurity in a time of transition. IFPRI-WFP Country Policy Note. Cairo, Egypt.

18 - EGYPT Nutrition L a n d s c a p e Analysis Report 2012

19 - Mbuya, Mduduzi N.N., Memory Chideme, Bernard Chasekwa, and Vinod Mishra. 2010. Biological, Social, and Environmental Determinants of Low Birth Weight and Stunting among Infants and Young Children in Zimbabwe. Zimbabwe Working Papers, No.7.

20 - Calverton, Maryland, USA: ICF Macro. Adair, L. S. Growth of Filipino infants who differ in body proportions at birth. Am J Hum Biol 1989;1:673-682.

21 - World Health Organization, Report Of The Expert Consultation On The Optimal Duration Of Exclusive Breastfeeding, report of an expert consultation Geneva, Switzerland 28-30 march 2001

22 - EFSA Panel on Dietetic Products, Nutrition and Allergies (NDA), Scientific Opinion on the appropriate age for introduction of complementary feeding of infants. EFSA Journal 2009; 7(12): 1423 [38 pp.].

23 - Kavle J., Mehana S., Saleh G., Foaud M., Ramzy M., Hamed D., Hassan M., Khan G., Galloway R. Examining factors associated with stunting in Lower Egypt in comparison to Upper Egypt: Bridging the gap between cultural beliefs and feasible feeding practices through trial for improved practices (TIPs). USAID Report 2014. 
Table (1) Demographic and Infant's Clinical Characteristics

\begin{tabular}{|c|c|c|c|}
\hline Characteristics & \multicolumn{2}{|c|}{ Mean \pm SD } & Min. - Max. \\
\hline Age of mothers in years & \multicolumn{2}{|c|}{$26.0 \pm 4.9$} & $18-40$ \\
\hline Age at marriage in years & \multicolumn{2}{|c|}{$20.4 \pm 2.5$} & $15-30$ \\
\hline Age of mothers at birth of the infant & \multicolumn{2}{|c|}{$24.8 \pm 4.9$} & $17-39.5$ \\
\hline Age of infants in months & \multicolumn{2}{|c|}{$13.9 \pm 6.1$} & $6-24$ \\
\hline Number of family members & \multicolumn{2}{|c|}{$4.6 \pm 1.4$} & $3-9$ \\
\hline Characteristics & \multicolumn{2}{|c|}{$\mathrm{N}=\mathbf{2 0 0}(\%)$} & \\
\hline $\begin{array}{l}\text { Mothers' education } \\
\text { Basic or less } \\
\text { Secondary } \\
\text { University }\end{array}$ & $\begin{array}{l}33 \\
94 \\
73\end{array}$ & $\begin{array}{l}(16.5) \\
(47.0) \\
(36.5)\end{array}$ & \\
\hline $\begin{array}{l}\text { Mothers' Job } \\
\text { House wife } \\
\text { Working for cash }\end{array}$ & $\begin{array}{c}155 \\
45\end{array}$ & $\begin{array}{l}(77.5) \\
(22.5)\end{array}$ & \\
\hline $\begin{array}{l}\text { Social status } \\
\text { Low } \\
\text { High }\end{array}$ & $\begin{array}{c}135 \\
65\end{array}$ & $\begin{array}{l}(67.5) \\
(32.5)\end{array}$ & \\
\hline $\begin{array}{l}\text { Infants' gender } \\
\text { Girls } \\
\text { Boys }\end{array}$ & $\begin{array}{c}98 \\
102\end{array}$ & $\begin{array}{l}(49.0) \\
(51.0)\end{array}$ & \\
\hline $\begin{array}{l}\text { Infants' age } \\
6 \text { to }<12 \text { months } \\
12 \text { to }<18 \text { months } \\
18 \text { to } 24 \text { months }\end{array}$ & $\begin{array}{l}66 \\
57 \\
77\end{array}$ & $\begin{array}{l}(33.0) \\
(28.5) \\
(38.5)\end{array}$ & \\
\hline $\begin{array}{l}\text { Infant's order } \\
\text { First to third } \\
\text { Fourth or further }\end{array}$ & $\begin{array}{c}177 \\
23 \\
\end{array}$ & $\begin{array}{r}(88.5) \\
(11.5) \\
\end{array}$ & \\
\hline $\begin{array}{l}\text { Infants' weight at birth a } \\
\text { Normal } \\
\text { Below normal }\end{array}$ & $\begin{array}{c}177 \\
23 \\
\end{array}$ & $\begin{array}{r}(88.5) \\
(11.5) \\
\end{array}$ & \\
\hline $\begin{array}{l}\text { Current infants' Weight } \\
\text { Normal for age } \\
\text { Underweight } \\
\text { Overweight } \\
\end{array}$ & $\begin{array}{c}112 \\
50 \\
38\end{array}$ & $\begin{array}{l}(56.0) \\
(25.0) \\
(19.0) \\
\end{array}$ & \\
\hline $\begin{array}{c}\text { Infants' length for age } \\
\text { Normal } \\
\text { Stunted } \\
\end{array}$ & $\begin{array}{c}148 \\
52 \\
\end{array}$ & $\begin{array}{r}(74.0) \\
(26.0) \\
\end{array}$ & \\
\hline $\begin{array}{l}\text { History of diarrhea } \\
\text { No } \\
\text { Mild } \\
\text { Sever } \\
\end{array}$ & $\begin{array}{c}123 \\
66 \\
11 \\
\end{array}$ & $\begin{array}{c}(61.5) \\
(33.0) \\
(5.5)\end{array}$ & \\
\hline $\begin{array}{l}\text { History of cough } \\
\text { No } \\
\text { Cough only } \\
\text { With dyspnea }\end{array}$ & $\begin{array}{l}105 \\
79 \\
16\end{array}$ & $\begin{array}{c}(52.5) \\
(39.5) \\
(8.0)\end{array}$ & \\
\hline
\end{tabular}


Table (2) Age of Introduction of Different Food Items in Months and Complementary Feeding Assessment

\begin{tabular}{|c|c|c|c|}
\hline Characteristics & $\mathbf{N}$ & $(\%)$ & $\begin{array}{c}\text { Median } \\
(\text { Min - Max })\end{array}$ \\
\hline $\begin{array}{l}\text { Age on Weaning } N(\%) 192(96.0)^{\text {a }} \\
\quad<4 \text { month } \\
4 \text { to }<6 \text { months } \\
\geq 6 \text { months }\end{array}$ & $\begin{array}{c}37 \\
121 \\
34\end{array}$ & $\begin{array}{l}(19.3) \\
(63.0) \\
(17.7)\end{array}$ & $5(2-10)$ \\
\hline $\begin{array}{l}\text { Dairy products } N(\%) \quad 190(95.0)^{b} \\
<4 \text { month } \\
\quad 4 \text { to }<6 \text { months } \\
\geq 6 \text { months }\end{array}$ & $\begin{array}{c}20 \\
130 \\
40 \\
\end{array}$ & $\begin{array}{l}(10.5) \\
(68.4) \\
(21.1) \\
\end{array}$ & $5(2-11)$ \\
\hline $\begin{array}{l}\text { Grains, roots \& tubers } N(\%) 173(86.5)^{\mathrm{c}} \\
\quad<6 \text { month } \\
\quad 6 \text { to }<9 \text { month } \\
\geq 9 \text { month }\end{array}$ & $\begin{array}{c}106 \\
55 \\
12 \\
\end{array}$ & $\begin{array}{c}(61.3) \\
(31.8) \\
(6.9)\end{array}$ & $5(3-14)$ \\
\hline $\begin{array}{l}\text { Flesh foods } N(\%) 140(70.0)^{d} \\
<6 \text { month } \\
\quad 6 \text { to }<9 \text { month } \\
\geq 9 \text { month }\end{array}$ & $\begin{array}{c}5 \\
89 \\
46\end{array}$ & $\begin{array}{l}(3.6) \\
(63.6) \\
(32.8)\end{array}$ & $8(5-16)$ \\
\hline $\begin{aligned} \text { Eggs } & N(\%) 149(74.5) \\
< & 6 \text { month } \\
& 6 \text { to }<9 \text { month } \\
\geq & 9 \text { month }\end{aligned}$ & $\begin{array}{c}6 \\
117 \\
26\end{array}$ & $\begin{array}{l}(4.0) \\
(78.5) \\
(17.5)\end{array}$ & $7(5-14)$ \\
\hline $\begin{array}{l}\text { Legumes and nuts } N(\%) 116(58.0)^{\text {e }} \\
4 \text { to }<6 \text { months } \\
6 \text { to }<9 \text { month } \\
\geq 9 \text { month }\end{array}$ & $\begin{array}{c}56 \\
55 \\
5\end{array}$ & $\begin{array}{c}(48.3) \\
(47.4) \\
(4.3)\end{array}$ & $6(4-12)$ \\
\hline $\begin{array}{l}\text { Vitamin A rich foods } N(\%) 51(25.5)^{\mathrm{f}} \\
\quad<6 \text { month } \\
\quad \geq 6 \text { month }\end{array}$ & $\begin{array}{l}11 \\
40\end{array}$ & $\begin{array}{l}(21.6) \\
(78.4)\end{array}$ & $6(5-12)$ \\
\hline $\begin{array}{l}\text { Other fruits \&veg. } N(\%) 66(33.0) \\
\quad<6 \text { month } \\
\quad \geq 6 \text { month }\end{array}$ & $\begin{array}{l}21 \\
45 \\
\end{array}$ & $\begin{array}{l}(31.8) \\
(68.2) \\
\end{array}$ & $6(5-13)$ \\
\hline $\begin{array}{l}\text { Milk intake } N(\%) 120(60.0) \\
\quad<12 \text { month } \\
12 \text { to }<18 \text { month } \\
\geq 18 \text { month }\end{array}$ & $\begin{array}{l}34 \\
59 \\
27\end{array}$ & $\begin{array}{l}(28.3) \\
(49.2) \\
(22.5)\end{array}$ & $12(9-24)$ \\
\hline $\begin{array}{l}\text { Fortified baby foods } N(\%) 27(13.5) \\
\quad<6 \text { month } \\
\geq 6 \text { month }\end{array}$ & $\begin{array}{c}6 \\
21 \\
\end{array}$ & $\begin{array}{l}(22.2) \\
(77.8) \\
\end{array}$ & $5(4-9)$ \\
\hline $\begin{array}{l}\text { Complete stop of BF } \boldsymbol{N ( \% )} \mathbf{4 4 ( 2 2 . 0 )} \\
12 \text { to } 18 \text { moths } \\
\text { After } 18 \text { moths } \\
\end{array}$ & $\begin{array}{l}14 \\
30 \\
\end{array}$ & $\begin{array}{l}(31.8) \\
(68.2) \\
\end{array}$ & $18(12-24)$ \\
\hline $\begin{array}{l}\text { Complementary feeding assessment } \\
\text { a } \\
\text { Minimum dietary diversity } \\
\text { Minimum meal frequency } \\
\text { Minimum acceptable diet }\end{array}$ & $\begin{array}{c}61 \\
118 \\
53\end{array}$ & $\begin{array}{l}(31.8) \\
(61.5) \\
(27.6)\end{array}$ & \\
\hline \multicolumn{4}{|c|}{$\begin{array}{l}{ }^{a} \text { Eight infants were not weaned; percentages were taken out of } 192 \\
\mathrm{~b}^{\mathrm{b}} \text { The majority consumed yogurt }{ }^{\mathrm{c}} \text { The majority consumed rice and potatoes } \\
{ }^{\mathrm{d}} \text { The majority consumed chicken liver chicken meat and less frequently meat. } \\
\mathrm{e}^{\mathrm{e}} \text { The majority consumed bean and lentil } \\
\begin{array}{ll}{ }^{\mathrm{f}} \text { This group includes carrots, squash sweet potatoes, ripe mangoes, and apricots } \\
\text { Min: minimum } \quad \text { Max: maximum } & \text { BF: breastfeeding }\end{array}\end{array}$} \\
\hline
\end{tabular}


Table (3) Factors Affecting Normal Infants' Weight

\begin{tabular}{|c|c|c|c|c|c|}
\hline Characteristics & $\begin{array}{c}\text { Normal } \\
\text { N }(\%)\end{array}$ & $\begin{array}{c}\text { Abnormal } \\
\mathbf{N}(\%)\end{array}$ & $\mathbf{X}^{2}$ & $\begin{array}{c}\text { P- } \\
\text { Value }^{\text {a }}\end{array}$ & $\begin{array}{c}\text { Adjusted OR } \\
(95 \% \mathrm{CI})^{b}\end{array}$ \\
\hline $\begin{array}{l}\text { Mothers' age } \mathbf{c}^{\mathbf{c}} \\
\leq \text { median }(\mathrm{n}=114) \\
>\text { median }(\mathrm{n}=86)\end{array}$ & $\begin{array}{l}72(63.2) \\
40(46.5) \\
\end{array}$ & $\begin{array}{l}42(36.8) \\
46(53.5)\end{array}$ & 5.51 & 0.019 & $0.57(0.26-1.22)$ \\
\hline $\begin{array}{l}\text { Mothers education } \\
\text { Basic or less }(n=33) \\
\text { Secondary }(n=94) \\
\text { High education }(n=73)\end{array}$ & $\begin{array}{l}17(51.5) \\
51(54.3) \\
44(60.3)\end{array}$ & $\begin{array}{l}16(48.5) \\
43(45.7) \\
29(39.7)\end{array}$ & 0.93 & 0.63 & NI \\
\hline $\begin{array}{l}\text { Mothers' job } \\
\text { Housewife }(n=155) \\
\text { Work for cash }(n=45)\end{array}$ & $\begin{array}{l}93(60.0) \\
19(42.2) \\
\end{array}$ & $\begin{array}{l}62(40.0) \\
26(57.8) \\
\end{array}$ & 4.47 & 0.034 & $0.66(0.23-1.91)$ \\
\hline $\begin{array}{l}\text { Social status } \\
\text { Low }(\mathrm{n}=135) \\
\text { High }(\mathrm{n}=65)\end{array}$ & $\begin{array}{l}75(55.6) \\
37(56.9)\end{array}$ & $\begin{array}{l}60(44.4) \\
28(43.1)\end{array}$ & 0.03 & 0.86 & NI \\
\hline $\begin{array}{l}\text { Infants' gender } \\
\text { Girls }(\mathrm{n}=98) \\
\text { Boys }(\mathrm{n}=102)\end{array}$ & $\begin{array}{l}49(50.0) \\
63(61.8) \\
\end{array}$ & $\begin{array}{l}49(50.0) \\
39(38.2) \\
\end{array}$ & 2.81 & 0.09 & $0.84(0.38-2.96)$ \\
\hline $\begin{array}{l}\text { Infant's order } \\
1^{\text {st }} \text { to } 3^{\text {rd }}(n=177) \\
4^{\text {th }} \text { or further }(n=23)\end{array}$ & $\begin{array}{c}103(58.2) \\
9(39.1) \\
\end{array}$ & $\begin{array}{l}74(41.8) \\
14(60.9) \\
\end{array}$ & 3.00 & 0.08 & $0.95(0.44-2.08)$ \\
\hline $\begin{array}{l}\text { Infants' wt. at birth } \\
\text { Normal }(\mathrm{n}=177) \\
\text { Below normal }(\mathrm{n}=23)\end{array}$ & $\begin{array}{c}106(59.9) \\
6(26.1)\end{array}$ & $\begin{array}{l}71(40.1) \\
17(73.9)\end{array}$ & 9.44 & 0.002 & $3.89(1.07-14.22)$ \\
\hline $\begin{array}{l}\text { Age on Weaning } \\
<6 \text { months }(n=158) \\
\geq 6 \text { months }(n=34)\end{array}$ & $\begin{array}{c}103(65.2) \\
9(26.5)\end{array}$ & $\begin{array}{l}55(34.8) \\
25(73.5)\end{array}$ & 17.26 & 0.000 & $2.37(0.31-18.21)$ \\
\hline $\begin{array}{l}\text { Dairy products } \\
<4 \text { month }(\mathrm{n}=20) \\
4 \text { to }<6 \text { month }(\mathrm{n}=130) \\
\geq 6^{\text {th }} \text { month }(\mathrm{n}=40)^{\mathrm{d}}\end{array}$ & $\begin{array}{l}5(25.0) \\
96(73.8) \\
11(27.5) \\
\end{array}$ & $\begin{array}{l}15(75.0) \\
34(26.2) \\
29(72.5)\end{array}$ & 37.80 & 0.000 & $\begin{array}{l}0.88(0.19-4.13) \\
2.25(0.96-14.97)\end{array}$ \\
\hline $\begin{array}{l}\text { Grains, roots \& tubers } \\
<6 \text { month }(\mathrm{n}=106) \\
6 \text { to }<9 \text { month }(\mathrm{n}=55) \\
\geq 9 \text { month }(\mathrm{n}=12)^{\mathrm{d}}\end{array}$ & $\begin{array}{c}68(64.2) \\
38(69.1) \\
1(8.3) \\
\end{array}$ & $\begin{array}{l}38(35.8) \\
17(30.9) \\
11(91.7) \\
\end{array}$ & 16.03 & 0.000 & $\begin{array}{l}1.68(0.16-17.28) \\
4.11(0.48-35.52)\end{array}$ \\
\hline $\begin{array}{l}\text { Protein food }^{\mathrm{e}} \\
<6 \text { month }(\mathrm{n}=7) \\
6 \text { to }<9 \text { month }(\mathrm{n}=121) \\
\geq 9 \text { month }(\mathrm{n}=34)^{\text {d }}\end{array}$ & $\begin{array}{c}3(42.9) \\
80(66.1) \\
15(44.1) \\
\end{array}$ & $\begin{array}{l}4(57.1) \\
41(33.9) \\
19(55.9) \\
\end{array}$ & 6.33 & 0.042 & $\begin{array}{l}1.05(0.33-14.9) \\
2.93(0.40-21.73)\end{array}$ \\
\hline $\begin{array}{l}\text { Legumes and nuts } \\
4 \text { to }<6 \text { months }(\mathrm{n}=56) \\
6 \text { to }<9 \text { month }(\mathrm{n}=55) \\
\geq 9 \text { month }(\mathrm{n}=5)\end{array}$ & $\begin{array}{c}30(53.6) \\
38(69.1) \\
2(40.0) \\
\end{array}$ & $\begin{array}{c}26(46.4) \\
17(30.9) \\
3(60.0) \\
\end{array}$ & 3.70 & 0.158 & $\mathrm{NI}$ \\
\hline $\begin{array}{l}\text { Milk intake } \\
<12 \text { month }(\mathrm{n}=34) \\
12 \text { to }<18 \text { month }(\mathrm{n}=59) \\
\geq 18 \text { month }(\mathrm{n}=27)\end{array}$ & $\begin{array}{l}19(55.9) \\
39(66.1) \\
13(48.1) \\
\end{array}$ & $\begin{array}{l}14(44.1) \\
20(33.9) \\
14(51.9)\end{array}$ & 2.68 & 0.261 & $\mathrm{NI}$ \\
\hline $\begin{array}{l}\text { History of diarrhea } \\
\text { No }(\mathrm{n}=123) \\
\text { Mild }(\mathrm{n}=66) \\
\text { Sever }(\mathrm{n}=11)^{\mathrm{d}}\end{array}$ & $\begin{array}{c}79(64.2) \\
31(47.0) \\
2(18.2) \\
\end{array}$ & $\begin{array}{c}44(35.8) \\
35(53.0) \\
9(81.8)\end{array}$ & 11.95 & 0.003 & $\begin{array}{l}2.01(0.29-15.28) \\
2.05(0.27-15.56)\end{array}$ \\
\hline $\begin{array}{l}{ }^{\mathrm{a}} \text { Chi square test was used } \\
{ }^{\mathrm{d}} \text { The reference category } \\
\text { OR: Odds Ratio }\end{array}$ & \multicolumn{5}{|c|}{$\begin{array}{l}{ }^{\mathrm{b}} \text { Binary logistic regression was used }{ }^{\mathrm{c}} \mathrm{Mec} \\
{ }^{\mathrm{e}} \text { Protein foods included flesh foods and eggs }\end{array}$} \\
\hline
\end{tabular}

